\title{
Determination of element contents of commercial and homemade jams
}

\author{
Andrea Kántor - Loránd Alexa - Béla Kovács - Nikolett Czipa \\ University of Debrecen, Institute of Food Science, Debrecen \\ kantor.andrea@agr.unideb.hu
}

\begin{abstract}
SUMMARY
Various products could be prepared by using fruits as raw materials. In Hungary, the most popular fruit products are spirit, jams, preserves, juices and dried fruits. Jams are made from different fruits, with different fruit content, technology and additives. They can be used for different products or they can be consumed by themselves. These products and their related production processes have great traditions in Hungary. In addition, they are widely used.

The aim of our study was to determine the element content of jams and to compare these samples based on their micro-and macroelement content.

In this study, 26 fruit jams with different botanical origins were examined. 10 samples were commercial, and 16 samples were homemade products. The determination of micro- and macroelements was carried out by using Inductively Coupled Plasma Mass Spectrometer and Inductively Coupled Plasma Optical Emission Spectrometer. Different element contents were measured [B (249.7), Ca (422.6), Fe (259.9), K (769.8), Mg (280.2), Na (589.5), P (185.9), S (182.0), Al (27), Mn (55), Cu (65), Zn (66), Sr (88), Ba (137)]. Based on element contents, the jams showed statistical differences.
\end{abstract}

Keywords: commercial, homemade, jams, element contents

\section{INTRODUCTION}

During the years the fruit consumption was between 37 and $45 \mathrm{~kg}$ per capita in Hungary. People consume for example apple, cherry, plum, peach, banana in large quantities $(\mathrm{KSH})$. Most of the fruits are seasonal products. People can choose from different processing technologies, that these fruits can be used at any time of the year (Diósi and Sipos 2013). In Hungary the most popular fruit products are spirit, jams, dried fruits and juices.

Jams are preparations containing one or more types of fresh or preserved fruits, by using sugar, honey or sweeteners, prepared by cooking until the desired concentrations appear, and treated by preservatives, heat, or the combinations of these methods. The fruit used (fruit pulp) is partially wrapped in pieces and/or broken (shredded), its stock is typically jelly, fragmented or dense (MÉ 2-33/1/03). Jams are often used as the stuffing of bakery products, or could be consumed with pastas, but it is also common to eat them with bread or by itself.

Jams and fruits have high concentrations of antioxidant compounds and mineral content with high dietary effect (Tanács 2005). In the study of Diósi and Sipos (2013), it was found that in case of plum jam, changes were made after the heat treatment of plum, but no significant change occurred during storage. We can say that jams could have positive effects on our health.

Plants can take up elements from the environment, some of these elements can be found in the products made of them. Macro elements are needed for the plants, so they take them in large quantities. Microelements are also important and essential, but may be toxic in plants after exceeding a certain limit (Kötschaua et al. 2013).

Testing of element content was considered important in jams.

\section{MATERIAL AND METHODS}

In this study, micro- and macroelement contents of 26 (10 commercials and 16 homemade) jam samples were analysed (Table 1). The samples have the origin of Hungary (except: peach, orange and lemon jams). The homemade jam's fruits were grown in HajdúBihar County.

\section{Determination of element contents}

The digestion of jam samples was carried out according to the method of Kovács et al. (1996), and the determination of elements was carried out by using ICP-MS (Inductively Coupled Plasma Mass Spectrometry) (Thermo Scientific XSeries 2, Bremen, Germany) and ICP-OES (Inductively Coupled Plasma Optical Emission Spectrometer) (Thermo Scientific iCAP 6300, Cambridge, UK). The following elements were examined: B (249.7), Ca (422.6), Fe (259.9), K (769.8), Mg (280.2), Na (589.5), P (185.9), S (182.0), $\mathrm{Al}$ (27), Mn (55), Cu (65), Zn (66), Sr (88), Ba (137).

\section{Statistical analysis}

All analytical analyses were in triplicate. Data are described by using general terms (mean, standard deviation), One-Way ANOVA (LSD test) and Linear Discriminant Analysis (LDA). SPSS for Windows (version 13; SPSS Inc. Chicago, Illinois, USA) was used for the calculations. 
Properties of examined jam samples

\begin{tabular}{|c|c|c|c|c|c|}
\hline \multicolumn{2}{|r|}{ Commercial } & \multirow{2}{*}{$\begin{array}{c}\text { Fruit types } \\
\text { red seed fruit }\end{array}$} & \multirow{2}{*}{$\frac{\text { Place of origin }}{\text { no data }}$} & \multirow{2}{*}{$\begin{array}{c}\text { Distributor } \\
\text { Hungary }\end{array}$} & \multirow{2}{*}{$\frac{\text { Fruit content }(\%)}{50}$} \\
\hline $\mathrm{C} 1$ & Rosehip (Rosa canina) & & & & \\
\hline $\mathrm{C} 2$ & Blackberry (Rubus caesius) & red seed fruit & Hungary & Hungary & 60 \\
\hline $\mathrm{C} 3$ & Blueberry (Vaccinium myrtillus) & red seed fruit & Hungary & Hungary & 50 \\
\hline $\mathrm{C} 4$ & Plum (Prunus domestica) & red stone fruit & Hungary & Hungary & 350 \\
\hline C5 & Apricot (Prunus armeniaca) & yellow stone fruit & Hungary & Hungary & 60 \\
\hline C6 & Cherry (Cerasus vulgaris) & red stone fruit & Hungary & Hungary & 60 \\
\hline $\mathrm{C} 7$ & Strawberry (Fragaria ananasa) & red seed fruit & Hungary & Hungary & 60 \\
\hline $\mathrm{C} 8$ & Raspberry (Rubus ideaus) & red seed fruit & Hungary & Hungary & 60 \\
\hline C9 & Orange (Citrus sinensis) & yellow seed fruit & no data & Hungary & 28 \\
\hline $\mathrm{C} 10$ & Peach (Persica vulgaris) & yellow stone fruit & Greece & Hungary & 55 \\
\hline \multicolumn{6}{|c|}{ Homemade } \\
\hline $\mathrm{H} 1$ & Lemon (Citrus limon) & yellow seed fruit & no data & & \\
\hline $\mathrm{H} 3$ & Blackberry (Rubus caesius) & red seed fruit & Hajdú-Bihar & & \\
\hline $\mathrm{H} 4$ & Plum (Prunus domestica) & red stone fruit & Hajdú-Bihar & & \\
\hline H5 & Apricot (Prunus armeniaca) & yellow stone fruit & Hajdú-Bihar & & \\
\hline H6 & Cherry (Cerasus vulgaris) & red stone fruit & Hajdú-Bihar & & \\
\hline $\mathrm{H} 7$ & Strawberry (Fragaria ananasa) & red seed fruit & Hajdú-Bihar & & \\
\hline H8 & Raspberry (Rubus ideaus) & red seed fruit & Hajdú-Bihar & & \\
\hline $\mathrm{H} 9$ & Orange (Citrus sinensis) & yellow seed fruit & no data & & \\
\hline H10 & Peach (Persica vulgaris) & yellow stone fruit & Hajdú-Bihar & & \\
\hline H11 & Plum (Prunus domestica) & red stone fruit & Hajdú-Bihar & & \\
\hline H12 & Plum (Prunus domestica) & red stone fruit & Hajdú-Bihar & & \\
\hline H13 & Plum (Prunus domestica) & red stone fruit & Hajdú-Bihar & & \\
\hline H14 & Plum (Prunus domestica) & red stone fruit & Hajdú-Bihar & & \\
\hline H15 & Bullace (Prunus domestica subsp. Syriaca) & yellow stone fruit & Hajdú-Bihar & & \\
\hline H16 & Cherry (Cerasus vulgaris) & red stone fruit & Hajdú-Bihar & & \\
\hline $\mathrm{H} 17$ & Strawberry (Fragaria ananasa) & red seed fruit & Hajdú-Bihar & & \\
\hline
\end{tabular}

\section{RESULTS AND DISCUSSION}

The macro- and microelement concentrations of the examined jam samples are shown in Table 2-3.

In case of boron content, the homemade jams (peach, orange, raspberry, apricot, blackberry, strawberry (H7) and cherry (H6) showed higher boron concentrations. Different boron contents were determined in plum jams. Similar boron concentrations were measured in $\mathrm{H} 11, \mathrm{H} 14$ and H15 samples.

Higher than $250 \mathrm{mg} \mathrm{kg}^{-1}$ calcium content was measured in $\mathrm{C} 1, \mathrm{C} 4, \mathrm{H} 3, \mathrm{H} 4, \mathrm{H} 7, \mathrm{H} 11, \mathrm{H} 12$ and $\mathrm{H} 13$ samples. Important difference was detected between $\mathrm{C} 2$ and $\mathrm{H} 3$ jams. In case of plum jams, the lowest concentrations were measured in $\mathrm{H} 14$ and $\mathrm{H} 15$ samples. The apricot and the raspberry pairwise had similar values. Calcium contents were similar in C6 and H6 cherry jams, but H16 sample showed lower concentration. In case of strawberry jams, H7 sample showed outstanding calcium content compared to other strawberry products. In commercial orange and peach jams the calcium contents were higher than in homemade orange and peach samples.

In terms of iron content, similar results were determined in blackberry, apricot and cherry jams. In homemade orange and peach jams the iron contents were higher than commercial jams. In case of commercial raspberry and commercial strawberry products, higher iron concentrations were measured than in homemade jams. Plum jams showed very different iron contents. The highest iron concentration was determined in H4 sample followed by H15 sample which contained high iron content too.

Examining the potassium content there was no important difference in case of apricot and strawberry jams. Homemade jams had higher calcium content than commercial blackberry, raspberry, orange, peach and $\mathrm{H} 6$ cherry jams. H4 plum jam showed the highest and $\mathrm{H} 15$ plum jam showed the lowest calcium content in case of plum jams.

In case of apricot products, the magnesium contents were similar. In blackberry, cherry (H6), strawberry, raspberry, orange and peach homemade jams the magnesium contents were higher than the same commercial jams. H4 plum jam had the highest and H15 plum jam had the lowest magnesium content in case of plum jams.

In homemade blackberry, plum, raspberry and orange jams the sodium contents were higher than in commercial samples, but in case of commercial cherry, strawberry and peach jams the sodium contents were higher. Outstanding sodium content was measured in homemade lemon jam. In apricot products the sodium contents were similar. 
Element concentrations of jam samples measured by ICP-OES ( $\left.\mathrm{mg} \mathrm{kg}^{-1}\right)$

\begin{tabular}{|c|c|c|c|c|c|c|c|c|}
\hline Sample number & B & $\mathrm{Ca}$ & $\mathrm{Fe}$ & $\mathrm{K}$ & $\mathrm{Mg}$ & $\mathrm{Na}$ & $\mathrm{P}$ & $\mathrm{S}$ \\
\hline $\mathrm{C} 1$ & $1.18 \pm 0.02$ & $297 \pm 7$ & $1.62 \pm 0.24$ & $724 \pm 59$ & $113 \pm 6$ & $43.0 \pm 4.4$ & $93.0 \pm 1.7$ & $35.2 \pm 1.6$ \\
\hline $\mathrm{C} 2$ & $0.731 \pm 0.146$ & $138 \pm 4$ & $3.87 \pm 0.24$ & $703 \pm 14$ & $88.2 \pm 0.8$ & $58.2 \pm 1.6$ & $85.6 \pm 3.7$ & $48.7 \pm 0.8$ \\
\hline $\mathrm{C} 3$ & $0.552 \pm 0.124$ & $117 \pm 15$ & $4.33 \pm 0.21$ & $284 \pm 5$ & $58.4 \pm 6.4$ & $126 \pm 5$ & $140 \pm 10$ & $105 \pm 8$ \\
\hline $\mathrm{C} 4$ & $11.8 \pm 0.1$ & $346 \pm 11$ & $5.37 \pm 0.12$ & $5371 \pm 158$ & $237 \pm 5$ & $22.4 \pm 2.6$ & $537 \pm 17$ & $89.0 \pm 1.0$ \\
\hline $\mathrm{C} 5$ & $2.02 \pm 0.10$ & $82.4 \pm 3.2$ & $1.98 \pm 0.46$ & $1338 \pm 48$ & $55.5 \pm 0.2$ & $25.1 \pm 1.1$ & $143 \pm 0$ & $35.1 \pm 0.2$ \\
\hline C6 & $3.58 \pm 0.51$ & $195 \pm 24$ & $3.36 \pm 0.30$ & $1220 \pm 162$ & $93.9 \pm 13.2$ & $130 \pm 10$ & $203 \pm 19$ & $55.6 \pm 6.7$ \\
\hline $\mathrm{C} 7$ & $0.278 \pm 0.172$ & $117 \pm 3$ & $4.36 \pm 0.23$ & $751 \pm 13$ & $64.4 \pm 0.6$ & $139 \pm 3$ & $193 \pm 4$ & $46.2 \pm 0.8$ \\
\hline $\mathrm{C} 8$ & $0.776 \pm 0.047$ & $103 \pm 12$ & $3.69 \pm 0.21$ & $803 \pm 0$ & $112 \pm 10$ & $22.0 \pm 0.2$ & $166 \pm 18$ & $57.0 \pm 6.5$ \\
\hline C9 & $0.166 \pm 0.045$ & $223 \pm 7$ & $0.442 \pm 0.074$ & $266 \pm 4$ & $28.5 \pm 0.5$ & $7.57 \pm 0.01$ & $34.9 \pm 0.1$ & $26.4 \pm 0.1$ \\
\hline $\mathrm{C} 10$ & $0.678 \pm 0.129$ & $59.1 \pm 1.5$ & $1.71 \pm 0.04$ & $329 \pm 1$ & $26.4 \pm 0.6$ & $287 \pm 2$ & $60.0 \pm 0.2$ & $27.4 \pm 0.9$ \\
\hline H1 & $1.11 \pm 0.44$ & $85.5 \pm 6.8$ & $0.802 \pm 0.059$ & $1073 \pm 315$ & $49.2 \pm 1.8$ & $268 \pm 14$ & $115 \pm 15$ & $34.4 \pm 2.8$ \\
\hline $\mathrm{H} 3$ & $1.25 \pm 0.13$ & $348 \pm 11$ & $3.45 \pm 0.26$ & $1173 \pm 2$ & $201 \pm 9$ & $126 \pm 1$ & $284 \pm 25$ & $377 \pm 11$ \\
\hline $\mathrm{H} 4$ & $11.1 \pm 0.3$ & $426 \pm 37$ & $194 \pm 7$ & $7626 \pm 125$ & $323 \pm 14$ & $30.9 \pm 1.8$ & $583 \pm 5$ & $85.3 \pm 2.4$ \\
\hline $\mathrm{H} 5$ & $3.28 \pm 0.01$ & $72.7 \pm 1.1$ & $2.17 \pm 0.00$ & $1594 \pm 28$ & $48.3 \pm 1.5$ & $30.3 \pm 0.5$ & $156 \pm 4$ & $63.9 \pm 1.0$ \\
\hline H6 & $7.67 \pm 0.12$ & $219 \pm 6$ & $4.12 \pm 0.45$ & $2555 \pm 21$ & $170 \pm 9$ & $41.3 \pm 1.0$ & $291 \pm 14$ & $127 \pm 11$ \\
\hline $\mathrm{H} 7$ & $0.858 \pm 0.149$ & $254 \pm 11$ & $3.22 \pm 0.27$ & $738 \pm 4$ & $133 \pm 3$ & $52.9 \pm 0.2$ & $228 \pm 4$ & $64.0 \pm 0.8$ \\
\hline H8 & $1.14 \pm 0.11$ & $107 \pm 1$ & $2.45 \pm 0.06$ & $1363 \pm 4$ & $150 \pm 4$ & $113 \pm 0$ & $193 \pm 0$ & $80.3 \pm 0.2$ \\
\hline H9 & $1.36 \pm 0.19$ & $184 \pm 8$ & $1.53 \pm 0.32$ & $1301 \pm 22$ & $83.6 \pm 3.6$ & $158 \pm 2$ & $192 \pm 1$ & $67.9 \pm 4.3$ \\
\hline H10 & $5.32 \pm 0.06$ & $37.6 \pm 0.3$ & $4.89 \pm 0.16$ & $1606 \pm 33$ & $72.9 \pm 0.4$ & $38.6 \pm 0.5$ & $268 \pm 0$ & $46.5 \pm 1.4$ \\
\hline H11 & $6.08 \pm 0.08$ & $284 \pm 7$ & $5.26 \pm 0.05$ & $4613 \pm 50$ & $232 \pm 7$ & $70.6 \pm 0.2$ & $415 \pm 2$ & $125 \pm 1$ \\
\hline $\mathrm{H} 12$ & $9.17 \pm 0.21$ & $383 \pm 29$ & $3.79 \pm 0.15$ & $5171 \pm 239$ & $243 \pm 15$ & $86.9 \pm 4.0$ & $520 \pm 11$ & $96.3 \pm 8.0$ \\
\hline H13 & $10.4 \pm 0.2$ & $253 \pm 3$ & $6.33 \pm 0.20$ & $4302 \pm 4$ & $208 \pm 4$ & $56.1 \pm 0.2$ & $482 \pm 2$ & $107 \pm 2$ \\
\hline H14 & $6.11 \pm 0.47$ & $177 \pm 2$ & $4.27 \pm 0.21$ & $3788 \pm 46$ & $187 \pm 5$ & $80.6 \pm 2.0$ & $392 \pm 14$ & $91.8 \pm 1.7$ \\
\hline H15 & $6.32 \pm 0.10$ & $110 \pm 4$ & $8.46 \pm 0.32$ & $3041 \pm 42$ & $82.4 \pm 0.9$ & $194 \pm 4$ & $295 \pm 2$ & $47.7 \pm 0.1$ \\
\hline H16 & $2.52 \pm 0.10$ & $140 \pm 2$ & $4.48 \pm 0.37$ & $1286 \pm 26$ & $92.6 \pm 5.6$ & $73.5 \pm 1.5$ & $160 \pm 3$ & $57.8 \pm 2.3$ \\
\hline H17 & $0.346 \pm 0.062$ & $103 \pm 25$ & $2.01 \pm 0.14$ & $911 \pm 0$ & $75.8 \pm 9$ & $88.9 \pm 3.3$ & $159 \pm 10$ & $40.8 \pm 5.6$ \\
\hline
\end{tabular}

Element concentration of jam samples measured by ICP-MS $\left(\mu \mathrm{g} \mathrm{kg}^{-1}\right)$

Table 3

\begin{tabular}{|c|c|c|c|c|c|c|}
\hline Sample number & $\mathrm{Al}$ & $\mathrm{Mn}$ & $\mathrm{Cu}$ & $\mathrm{Zn}$ & $\mathrm{Sr}$ & $\mathrm{Ba}$ \\
\hline $\mathrm{C} 1$ & $356 \pm 8$ & $2486 \pm 30$ & $331 \pm 30$ & $459 \pm 38$ & $1629 \pm 54$ & $811 \pm 8$ \\
\hline $\mathrm{C} 2$ & $2222 \pm 159$ & $6877 \pm 132$ & $429 \pm 14$ & $811 \pm 11$ & $736 \pm 20$ & $690 \pm 36$ \\
\hline $\mathrm{C} 3$ & $2923 \pm 129$ & $8214 \pm 500$ & $658 \pm 18$ & $1468 \pm 147$ & $530 \pm 41$ & $663 \pm 25$ \\
\hline $\mathrm{C} 4$ & $978 \pm 51$ & $2226 \pm 15$ & $2177 \pm 63$ & $5482 \pm 351$ & $1914 \pm 5$ & $600 \pm 21$ \\
\hline $\mathrm{C} 5$ & $279 \pm 78$ & $651 \pm 16$ & $443 \pm 9$ & $1007 \pm 104$ & $274 \pm 0$ & $1088 \pm 50$ \\
\hline C6 & $522 \pm 79$ & $1036 \pm 1$ & $1115 \pm 83$ & $875 \pm 8$ & $977 \pm 57$ & $392 \pm 30$ \\
\hline $\mathrm{C} 7$ & $2459 \pm 95$ & $2666 \pm 57$ & $283 \pm 17$ & $650 \pm 59$ & $698 \pm 20$ & $1222 \pm 45$ \\
\hline $\mathrm{C} 8$ & $147 \pm 4$ & $8682 \pm 320$ & $362 \pm 11$ & $1850 \pm 226$ & $461 \pm 19$ & $613 \pm 48$ \\
\hline C9 & $<$ LOD$^{*}$ & $143 \pm 3$ & $<\mathrm{LOD}^{*}$ & $238 \pm 21$ & $2335 \pm 85$ & $210 \pm 4$ \\
\hline $\mathrm{C} 10$ & $171 \pm 13$ & $133 \pm 11$ & $371 \pm 13$ & $412 \pm 54$ & $491 \pm 30$ & $178 \pm 18$ \\
\hline$\overline{\mathrm{H} 1}$ & $199 \pm 4$ & $200 \pm 15$ & $350 \pm 14$ & $515 \pm 23$ & $1748 \pm 120$ & $453 \pm 22$ \\
\hline $\mathrm{H} 3$ & $605 \pm 10$ & $7872 \pm 490$ & $879 \pm 2$ & $1979 \pm 250$ & $761 \pm 51$ & $402 \pm 21$ \\
\hline $\mathrm{H} 4$ & $2515 \pm 103$ & $2972 \pm 54$ & $1876 \pm 37$ & $5811 \pm 564$ & $2401 \pm 120$ & $696 \pm 4$ \\
\hline H5 & $866 \pm 18$ & $530 \pm 3$ & $224 \pm 18$ & $1568 \pm 115$ & $238 \pm 5$ & $58.2 \pm 3.0$ \\
\hline H6 & $286 \pm 15$ & $1416 \pm 138$ & $346 \pm 6$ & $1097 \pm 40$ & $768 \pm 52$ & $195 \pm 16$ \\
\hline $\mathrm{H} 7$ & $1223 \pm 124$ & $2346 \pm 147$ & $353 \pm 12$ & $1001 \pm 105$ & $1363 \pm 70$ & $1222 \pm 40$ \\
\hline $\mathrm{H} 8$ & $644 \pm 8$ & $1816 \pm 27$ & $510 \pm 12$ & $1789 \pm 97$ & $513 \pm 13$ & $142 \pm 1$ \\
\hline H9 & $200 \pm 8$ & $227 \pm 4$ & $403 \pm 12$ & $999 \pm 45$ & $704 \pm 51$ & $252 \pm 13$ \\
\hline $\mathrm{H} 10$ & $466 \pm 37$ & $653 \pm 20$ & $553 \pm 13$ & $1370 \pm 27$ & $125 \pm 8$ & $54.1 \pm 1.2$ \\
\hline H11 & $1804 \pm 86$ & $2369 \pm 3$ & $1728 \pm 90$ & $2142 \pm 223$ & $1852 \pm 64$ & $353 \pm 5$ \\
\hline $\mathrm{H} 12$ & $1223 \pm 59$ & $3053 \pm 255$ & $1529 \pm 98$ & $2404 \pm 237$ & $2086 \pm 100$ & $452 \pm 18$ \\
\hline H13 & $1861 \pm 73$ & $2527 \pm 75$ & $1897 \pm 23$ & $2830 \pm 83$ & $1410 \pm 47$ & $221 \pm 10$ \\
\hline H14 & $1482 \pm 100$ & $2541 \pm 76$ & $1241 \pm 54$ & $1663 \pm 129$ & $1351 \pm 43$ & $356 \pm 16$ \\
\hline H15 & $1803 \pm 72$ & $823 \pm 43$ & $<$ LOD $^{*}$ & $1288 \pm 107$ & $399 \pm 13$ & $383 \pm 30$ \\
\hline H16 & $<\mathrm{LOD}^{*}$ & $646 \pm 36$ & $732 \pm 18$ & $584 \pm 51$ & $796 \pm 25$ & $128 \pm 9$ \\
\hline $\mathrm{H} 17$ & $227 \pm 4$ & $1093 \pm 107$ & $209 \pm 11$ & $1545 \pm 59$ & $492 \pm 44$ & $283 \pm 16$ \\
\hline
\end{tabular}

Note: *limit of detection (LOD) values: Al: $66.4 \mu \mathrm{g} \mathrm{kg}^{-1}$; Cu: $188 \mu \mathrm{g} \mathrm{kg}^{-1}$ 
The apricot jam showed similar results in the phosphorus contents. However, in homemade jams (blackberry, cherry (H6), strawberry $(\mathrm{H} 7)$, raspberry, orange and peach) higher phosphorus content was measured. Plum jams had variable results. The highest phosphorus content was measured in $\mathrm{H} 4$ and the lowest was measured in H15 samples.

The sulphur content was higher in homemade jams. Outstanding sulphur content was measured in the homemade blackberry sample. H15 sample had the lowest sulphur content among the plums. It should be noted that H16 sample showed similar value to the commercial cherry jam. In H7 strawberry jam we measured lower concentration than in the commercial sample.

The highest aluminium content was measured in C3 sample. Analysing the homemade jams, higher aluminium contents were determined in plum, apricot, raspberry, orange and peach samples. Commercial blackberry, sour cherry and strawberry jams showed higher aluminium contents.

The highest manganese contents were measured in commercial raspberry, blueberry and blackberry jams. In other jams the manganese contents were below $3000 \mu \mathrm{g} \mathrm{kg}^{-1}$.

The highest copper content was determined in plum jams (C4, H4, H11-H15), followed by C6 and H16 samples and homemade blackberry and peach jams. The other jams had less than $500 \mu \mathrm{g} \mathrm{kg}^{-1}$ copper concentrations.

The highest zinc contents were measured in $\mathrm{C} 4$ and H4 samples. In homemade blackberry, apricot, strawberry, orange and peach jams the zinc contents were higher than in commercial samples.

Lower than $1000 \mu \mathrm{g} \mathrm{kg}^{-1}$ strontium content was measured in the following jams: rosehip, plum jams (C4, H4, H11, H12, H13 and H14) and strawberries (H7), commercial orange and homemade lemon jams. Similar results were measured in blackberry, apricot, cherry and raspberry jams.

Barium content was the highest in $\mathrm{C} 7$ and $\mathrm{H} 7$ strawberry jams followed by commercial apricot jam. High barium content was also measured in $\mathrm{C} 1, \mathrm{C} 2$, C3, C4, H4 and C8 samples.

Examined samples were classified based on different properties. In the first step the samples were classified by their colours therefore 18 samples from red and 8 samples from yellow fruits were analysed. Independent-Samples $\mathrm{T}$ test was used to verify the differences between these two groups where the grouping variables were the colours. Based on the results statistically verified differences were determined in some elements $(\mathrm{P}$ value $<0.05)$ : $\mathrm{Ca}(\mathrm{P}$ value $=0.002), \mathrm{Mg}(\mathrm{P}$ value $=0.002), \mathrm{P}(\mathrm{P}$ value $=0.050)$, $\mathrm{S}(\mathrm{P}$ value $=0.015), \mathrm{Al}(\mathrm{P}$ value $=0.041), \mathrm{Mn}(\mathrm{P}$ value $=$ $0.004)$ and $\mathrm{Zn}(\mathrm{P}$ value $=0.020)$.

In the next step, the samples were classified based on their seed types, therefore 14 samples from stone fruits 12 samples from seed fruits were analysed. Based on the Independent-Samples $\mathrm{T}$ test the differences were statistically verified in case of the following elements: $\mathrm{B}(\mathrm{P}$ value $=0.000), \mathrm{K}(\mathrm{P}$ value $=$ $0.001), P(P$ value $=0.004), \mathrm{Mn}(\mathrm{P}$ value $=0.043)$ and $\mathrm{Cu}(\mathrm{P}$ value $=0.006)$.

The samples were grouped in four groups to carry out of One-Way ANOVA and LDA; therefore 9 samples from red seed fruits, 9 samples from red stone fruits, 3 samples from yellow seed fruits and 5 samples from yellow stone fruits were analysed. In case of 5 elements $(\mathrm{B}, \mathrm{K}, \mathrm{Na}, \mathrm{Mn}$ and $\mathrm{Cu})$, the $\mathrm{P}$ values were lower than 0.01 (the variances were heterogeneous), so the Dunett T3 test was used. In case of other elements, the variances were homogenous, so LSD test was used. According to results the difference was statistically verified in case of the following samples:

- red seed fruit+red stone fruit: $\mathrm{B}(\mathrm{P}$ value $=0.001)$, $\mathrm{K} \quad(\mathrm{P}$ value $=0.009), \mathrm{Cu} \quad(\mathrm{P}$ value $=0.006), \mathrm{a}(\mathrm{P}$ value $=0.032), \mathrm{Mg}(\mathrm{P}$ value $=0.002), \mathrm{P}(\mathrm{P}$ value $=$ $0.000), \mathrm{Zn}(\mathrm{P}$ value $=0.039), \mathrm{Sr}(\mathrm{P}$ value $=0.007)$;

- red seed fruit+yellow seed fruit: $\mathrm{Mn}(\mathrm{P}$ value $=$ $0.014), \mathrm{Sr}(\mathrm{P}$ value $=0.044)$

- red seed fruit+yellow stone fruit: $\mathrm{Mn}(\mathrm{P}$ value $=$ $0.023), \mathrm{Ca}(\mathrm{P}$ value $=0.043)$;

- red stone fruit+yellow seed fruit: $\mathrm{B}(\mathrm{P}$ value= $0.001), K(P$ value $=0.012), \mathrm{Mn}(\mathrm{P}$ value $=0.001)$, $\mathrm{Cu}(\mathrm{P}$ value $=0.005), \mathrm{Mg}(\mathrm{P}$ value $=0.001), \mathrm{P}(\mathrm{P}$ value $=0.001), \mathrm{Zn}(\mathrm{P}$ value $=0.025)$;

- red stone fruit+yellow stone fruit: $\mathrm{Mn}(\mathrm{P}$ value $=$ $0.003), \mathrm{Cu}(\mathrm{P}$ value $=0.005), \mathrm{Ca}(\mathrm{P}$ value $=0.000)$, $\mathrm{Mg}(\mathrm{P}$ value $=0.000), \mathrm{P}(\mathrm{P}$ value $=0.002), \mathrm{Zn}(\mathrm{P}$ value $=0.049), \mathrm{Sr}(\mathrm{P}$ value $=0.000)$;

- yellow seed fruit+yellow stone fruit: $\mathrm{Sr}(\mathrm{P}$ value= 0.005).

LDA analysis was carried out to differentiate the examined samples. Grouping variables were the colour and seed type; the independents were the $\mathrm{Ca}$, $\mathrm{K}, \mathrm{Mg}, \mathrm{Na}, \mathrm{P}$ and $\mathrm{S}$. Based on Wilks' Lambda values Mg (0.423), K (0.427) and P (0.444) had the highest effect and these three variables were significant. Three discriminant functions were determined by the program with eigenvalues of $2.38,1.39$ and 0.311 . The first function explained $70.4 \%$ of the variance of variables, the second one explained $58.2 \%$ and the third one explained $23.7 \%$. The first function involved $\mathrm{S}$, the second one involved $\mathrm{K}, \mathrm{P}$ and $\mathrm{Mg}$ and the third one involved $\mathrm{Ca}$ and $\mathrm{Na}$.

Centroids of discriminant functions are illustrated in Figure 1.

In the first dimension, group 4 showed the highest centroid (2.35) followed by group 3 (1.42), group 2 $(-0.376)$ and group $1(-1.40)$. In the second dimension the highest centroid was determined in group $2(1.44)$ followed by group $4(-0.238)$, group $1(-0.0964)$ and group $3(-1.04)$. Centroids were different in the first dimension, however in the second dimension group 1 and group 3 showed very similar values.

Based on plot, centroids of certain samples are nearer to a centroid of another group. It also was verified by classification results. 
Figure 1: Linear discriminant analysis of jams (macro elements)

Canonical Discriminant Functions

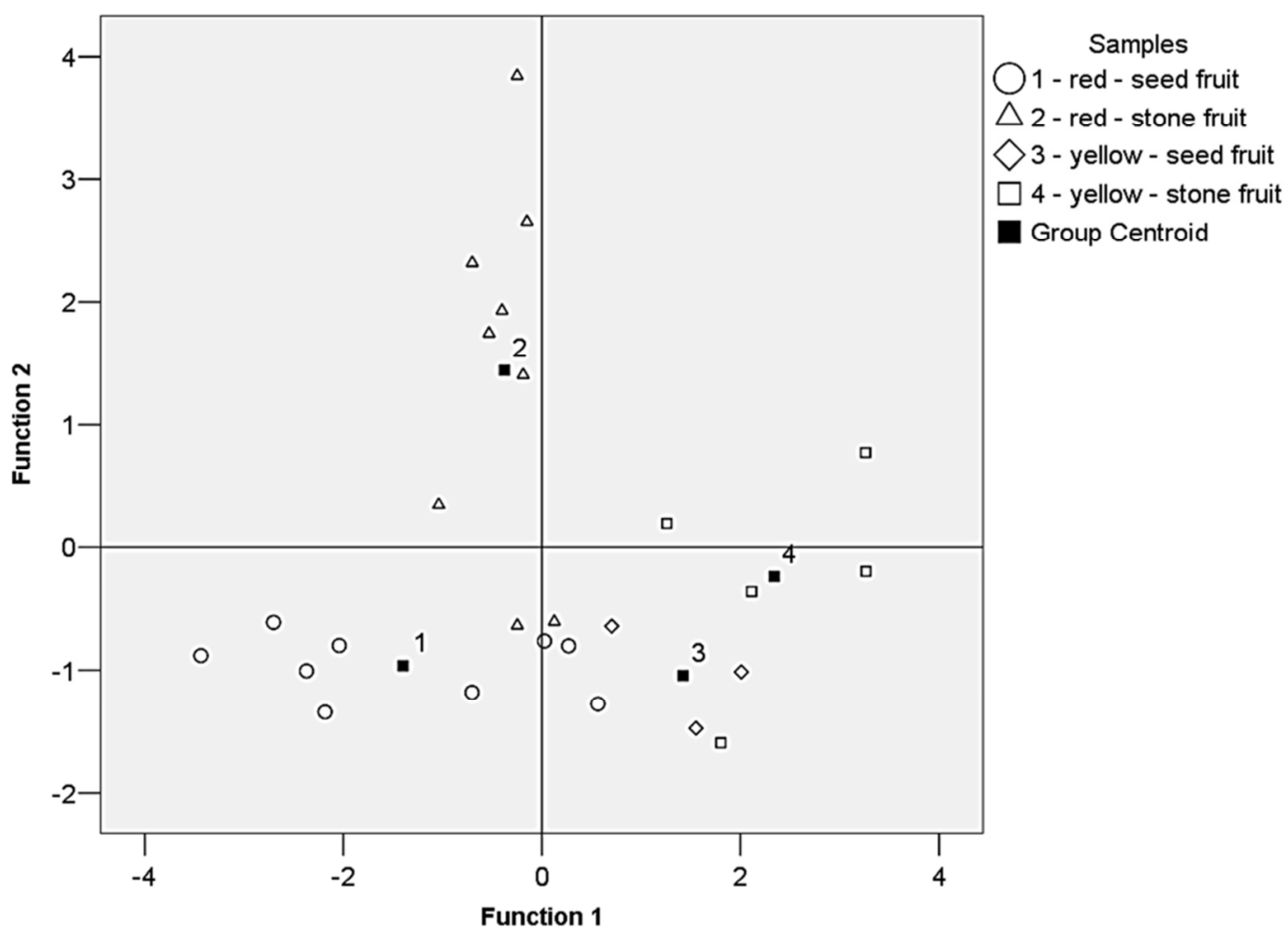

In case of group 1, only 6 from 9 samples are in the same group, 1 sample (H3) moved into group 2 and 2 samples (C3 and C7) moved into group 3. In case of group 2, 3 samples (C6, H6 and H16) moved into group 1. In case of group 3, 2 samples (C9 and H1) moved into group 4 and in case of group 4, 1 sample (H10) moved into group 2 and 1 sample (C10) was moved into group 3. According to the cross validation, $61.5 \%$ of cross-validated grouped cases were correctly classified.

In the last step, the correlations were examined among the examined elements. In case of some elements the correlation values were high $\left(\mathrm{r}^{2}>0.8\right)$ : K-P (0.944), K-B (0.925), B-P (0.914), Mg-P (0.906), $\mathrm{P}-\mathrm{Cu}$ (0.894), K-Cu (0.874), K-Mg (0.871),
B-Cu (0.850), K-Zn (0.842), P-Zn (0.835), Ca-Mg (0.829), $\mathrm{Mg}-\mathrm{Cu}(0.822)$ and $\mathrm{Mg}-\mathrm{Zn}(0.804)$.

\section{CONCLUSION}

The element content of jams depends on a large extent on the place of production, the kind of fruit, the fruit content of jams, the method of preparation and the additives. Based on the statistical analyses, we can see that jams can be separated based on the elements, the colour of the jams, the seed types and their combinations.

In the future, we are planning to examine the ingredients, the most popular and the best parameters for jams.

\section{REFERENCES}

Diósi G.-Sipos P. (2013): Különféle szilvafajtákból készült lekvárok minőségének vizsgálata többéves tárolás után. „Fiatal kutatók az egészséges élelmiszerért" tudományos ülés. Debrecen. 9-14.

Kovács, B.-Győri, Z.-Prokisch, J.-Loch, J.-Dániel, P. (1996): A study of plant sample preparation and inductively coupled plasma emission spectrometry parameters. Communications in Soil Science and Plant Analysis. 27: 1177-1198.
Kötschaua, A.-Büchela, G.-Einaxd, J. W.-Fischerbc, C.-von Tümplinge, W.-Mertena, D. (2013): Mapping of macro- and microelements in the leaves of sunflower (Helianthus annuus) by Laser Ablation-ICP-MS. Microchemical Journal. 110: 783789.

KSH: https://www.ksh.hu/docs/hun/xstadat/xstadat_eves/i_zhc023c. html?down=6434

MÉ 2-33/1/03: Magyar Élelmiszerkönyv. Lekvárfélék.

Tanács L. (2005): Élelmiszeripari nyersanyagismeret. Szaktudás Kiadó Ház. Budapest. 153-155. 